\title{
Egalitarian dialogue and instrumental dimension. Two princi- ples of dialogic learning in the classroom
}

\author{
Sandra Racionero Plaza* \\ University of Wisconsin-Madison \\ (Received March 16, 2010; Accepted April 23, 2010)
}

\begin{abstract}
Dialogic conceptualizations of learning have rapidly arisen in the last two decades. Building upon Vygotsky's socio-cultural psychology, these theories emphasize that people make meaning in interaction with others, where language is the main mediational tool. One of those accounts is the theory of "dialogic learning" (Flecha, 2000). This article explores two of the principles of dialogic learning: egalitarian dialogue and instrumental dimension, through the meanings that a group of elementary school children gave to learning in interactive groups, a practice of dialogic learning in the classroom. The data revealed the meanings that students gave to those two principles of dialogic learning and how each of those principles gets manifested in interactive groups. Regarding egalitarian dialogue, children perceived that participants in interactive groups hold validity claims, engage in communicative action, and care about the effects and context of the interactions. As for the principle of instrumental dimension, the students pointed out multiple ways in which dialogue act as a tool to learn more, for example, facilitating the identification of gaps and errors in one's reasoning and fostering the development of communicative abilities.
\end{abstract}

Key words: dialogic learning, dialogue, interaction, interactive groups.

Diálogo igualitario y dimensión instrumental. Dos principios del aprendizaje dialógico en el aula

RESUMEN: En las dos últimas décadas han surgido con rapidez conceptualizaciones dialógicas del aprendizaje. Basándose en la psicología socio-cultural de Vygotsky, estas teorías enfatizan que las personas crean significado en la interacción social, donde el lenguaje es la principal herramienta mediacional. Una de esas teorías es la del "aprendizaje dialógico" (Flecha, 2000).Este artículo explora dos de los principios del aprendizaje dialógico: diálogo igualitario y dimensión instrumental, a través de los significados que un grupo de niñas y niños de educación primaria dan a aprender en grupos interactivos, una práctica de aprendizaje dialógico en el aula. Los datos revelaron lo que significa para las y los estudiantes esos dos principios del aprendizaje dialógico, así como la forma cómo cada uno de ellos se manifiesta en los grupos interactivos. Relacionado con el diálogo igualitario, las niñas y niños percibieron que las y los participantes en grupos interactivos tienen pretensiones de validez, participan de acción comunicativa, y se preocupan por los efectos y el contexto de las interacciones. Sobre el principio de dimensión instrumental, las y los estudiantes destacaron múltiples formas en las que el diálogo actúa como herramienta para aprender más, por ejemplo facilitando la identificación de lagunas y errores en el propio razonamiento y fomentando 
el desarrollo de habilidades comunicativas.

Palabras clave: aprendizaje dialógico, diálogo, interacción, grupos interactivos.

\section{INTRODUCTION}

In the last two decades, a move from schemata (Anderson, 1993; Chi, Feltovich, \& Glaser; Pinker, 1997) to interaction and dialogue has been predominant in the field of the learning science. This dialogic shift (Aubert \& Soler, 2006) has its roots in cultural-historical psychology and, in particular, in the work of the Russian psychologist L. S. Vygostky $(1962,1978)$. Contemporary sociocultural research has extended Vygotsky's dialogic view of learning, developing the idea that learning is always situated in communities of practice (Wenger, 1998), where its members share ways of knowing and solving problems and usually a common identity (Hutchins, 1995; Lave, 1988; Lave \& Wenger, 1991; Rogoff, 1990).

In addition to viewing learning as an activity that takes place between people and in community contexts, these socio-cultural conceptualizations coincide in seeing language as the most powerful tool mediating learning (Vygotsky, 1962). In turn, language allows sharing focus and purpose (Rogoff, 1990), facilitates the understanding of the mind of others (Bruner, 1996), and aids reaching understanding (Habermas, 1987). Language makes intersubjectivity possible, which ultimately implies that knowledge is constructed between people engaged in dialogue (Edwards \& Mercer, 1987; Flecha, 2000; Wells, 1999). This is the foundational premise of a new field of study focused on the study of knowing through dialogue.

The study conducted explored the seven principles of dialogic learning. This article reports a piece of that study; it focuses on the results for the principles of egalitarian dialogue and instrumental dimension. Apart from length constraints, this selection responds to the richness of the data for those principles, and to its relevance in relation to prior research in the field. Few studies have looked at issues of equity when learning through dialogue and at the perceptions of children in regard to using language as a tool for school learning.

\section{KNOWING THROUGH DIALOGUE}

While dialogic learning has been a popular area of research in recent years, the idea of learning through dialogue is not new. Dialogic learning is frequently associated with Socratic dialogues (Benson, 2000) and Bakhtin (1986) placed major emphasis on the dialogicality of discourse. In the 70's, Freire (2003) developed a theory of dialogic action that pointed out the dialogic nature of humans and the importance of dialogue as a tool for raising critical consciousness. Habermas' $(1984,1987)$ theory of communicative action has emphasized that it is by means of argumentation based on validity claims that greater levels of understanding are achieved. In the educational sciences, Wells (1999) has developed 
a dialogic inquiry approach to the curriculum on the basis that inquiry-based learning is afforded by dialogue.

Dialogic approaches to knowing and coming to know emphasize that mental activity has it roots in social relations and communication, and claim that learning is likely to be most effective when learners are actively involved in the dialogic creation of meaning about topics that are important to them (Mercer, 2000; Tharp \& Gallimore, 1988;Wells, 2001; Wells \& Mejía-Arauz, 2006). This implies that "students' opportunities for learning and knowing are crucially dependent on the nature of the activities in which they engage and on the functions that language performs in these activities" (Wells, 2001, p.184). Further, research in this approach has also explored how issues such as language, culture, and inequality affect interactions and learning opportunities (Aubert, Flecha, García, Flecha \& Racionero, 2008; Freire, 2003).

\section{THE THEORY OF DIALOGIC LEARNING}

The theory of dialogic learning (Flecha, 2000; Aubert et al, 2008) maintains that learners reach deep understandings of subject knowledge and engage in processes of personal and social transformation through dialogues that are egalitarian, recognize and build upon each person's cultural intelligence, seek transformation, enhance the instrumental dimension of dialogue, are based on the value of solidarity, act as sources of creation of meaning, and rely on and promote equality of differences. These are the seven principles of dialogic learning. Because this article focuses on the principles of egalitarian dialogue and instrumental dimension, the theoretical explanation of dialogic learning that follows relates to those two principles.

\section{Egalitarian dialogue}

"Dialogue is egalitarian when it takes different contributions into consideration according to the validity of their reasoning, instead of according to the positions of power held by those who make the contributions" (Flecha, 2000, p.2). Specifically, for egalitarian dialogue to occur, speakers must hold validity claims (Habermas, 1987), engage in communicative action (Habermas, 1987), and care about the effects and context of their interactions (Searle \& Soler, 2004).

Validity claims (Habermas, 1987) refer to a willingness to engage in discourse using arguments to support one's opinions rather than any form of power, and accepting that another person's ideas might modify your own, regardless of the status of the other person. In egalitarian dialogue, speakers hold validity claims "(...) since they all construct interpretations based on the contributions made. Nothing can be taken as definitively concluded, as assertions will always be subject to future analysis" (Flecha, 2000, p.2). In addition, egalitarian dialogues are expressions of communicative action because all participants in the interaction are driven by the purpose of attaining an agreement that can serve as a basis for 
an agreed coordination of the action plans. In other words, in egalitarian dialogues, participants have to make a constant attempt to understand each other's perspectives- to achieve a state of intersubjectivity.

However, claims or pretensions are not enough for egalitarian dialogue to occur. Due to social inequalities, some people hold higher status than others, and therefore exert certain degree of symbolic violence, although that might not be their intention nor are they always conscious of it. To reduce the effects of our unequal social structure on communication, participants in the interaction have to be concerned not only about their intentions but also about their social positioning, thus caring about the effects and context of interactions (Searle \& Soler, 2004).

\section{Instrumental dimension}

Dialogue is not in opposition to instrumental learning. Vygotsky (1962) emphasized humans' deliberate use of tools for accomplishing individual and collective purposes and, among all symbolic tools, he saw language as the most important one in leading learning and development (Vygotsky, 1981). George Herbert Mead (1934) also pointed out that it is through conversation of gestures, including language, that one can take up the perspective of the "generalized other" and respond to it, what Mead saw as driving cognitive development. Contemporary research has demonstrated that language based actions, such as explaining, reasoning, and asking questions are instruments for encouraging thinking, the development of knowledge and metacognition (Bereiter \& Scardamalia, 1987; Fisher, 2007; Frijters, ten Dam, \& Rijlaarsdam, 2008; Mercer, 2000; Renshaw, 2004; Salomon \& Perkins, 1998; Wegerif, Mercer, \& Dawes, 1999).

\section{METHODS}

The study involved a total of 24 children from two elementary schools in Catalonia (Spain). These two schools were purposefully selected for two reasons. First, both schools are engaged in the Learning Communities project where interactive groups are employed. The Learning Communities program is aimed at overcoming school failure and improving coexistence in schools and neighborhoods (Elboj, Puigdellívol, Soler \& Valls, 2002). Currently, around 90 schools in Spain are engaged in this project raising the academic achievement of their students and fostering social cohesion (CREA, 2006-2011; Gatt, Ojala \& Soler, forthcoming).

Second, the selected schools have different population profiles. While the school in Tarragona mainly serves middle-class families, the school in Barcelona serves a working-class population, more racially and culturally diverse, with a number of families receiving attention from social services. The students ranged from five to twelve years old, the age range that corresponds to elementary edu- 
cation. They were nominated by their teachers following two criteria: students had participated in interactive groups for at least two years, and the group of students from each school had to be racially, ethnically, and culturally diverse, representing the criterion of heterogeneity of interactive groups. The final sample included girls and boys who were Spanish (non-Romaní), Moroccan, Romaní, Latinas/os and Rumanian students. All of them were engaged in interactive groups for the subjects of language and mathematics, or at least for one of them. Interactive groups (INCLUD-ED Consortium, 2009), an inclusive way of organizing classrooms framed by the theory of dialogic learning, were used as a proxy for dialogic learning. In interactive groups, four or five small groups of students are created. The criterion for group composition is maximum heterogeneity, in terms of mastery levels, culture, race, ethnicity, language, gender, life styles, etc. Adults from the community participate in the classroom promoting dialogue and solidarity in the groups with the objective that every student reaches the highest learning objectives. The activities in each group are approximately 20 minutes long, and after that time, each group moves to the next table and works on a different activity with a different adult.

This study was conducted with the critical communicative methodology (Gómez, Latorre, Sánchez \& Flecha, 2006). Data was collected through communicative focus groups since what was of interest were the students' explanations of how they learned in interactive groups, and it was expected that being in a group setting would facilitate children's elaboration of theirs and other children's thoughts, extending the individual argumentations. Seven focus groups were conducted at the schools; students were grouped with others they already knew. The discussion in the groups was managed by the researcher, and the questions discussed related to all principles of dialogic learning.

The data from each focus group was coded using seven main analytical categories, which corresponded to the seven principles of dialogic learning. This analysis used the theoretical concepts underlying each principle of dialogic learning as a way to operationalize the principles. This examination informed about how children understood each principle and how those were manifested in the learning environment of interactive groups. This article focuses on the findings for two of the principles of dialogic learning: egalitarian dialogue and instrumental dimension.

\section{FINDINGS}

\section{Egalitarian dialogue: learning grounded in the force of arguments}

From children's perspective, dialogues in interactive groups are egalitarian. In regard to validity claims, students perceived that in interactive groups the force of the arguments prevails over the arguments by force. For example, when sharing their opinions in the groups, students explained that they do not impose their thoughts using any form of symbolic or physical violence, such as screa- 
ming or fighting. María ${ }^{1}$ 's explanation of dialogue in interactive groups illustrates this: "We talk and in that process we see what some did wrong (...). We talk to each other very politely, no one screams, no one fights, nothing like that" (FG1M). In addition, children characterized the process of sharing one's views with others as "argumentative", describing the way to make others rectify their initial stances as consisting of showing the "right" arguments. As Pau explained:

So, instead of saying this is this, and this, and this (...) the issue is discussed until a good conclusion is reached, using the right arguments. (...) It is about telling him 'this is this way...' and we try to make him understand that it is that way because of this and that. (FG2PT).

Children also perceived volunteers promoting validity claims over power claims by asking students to support their thoughts with arguments or reasons:

So, the first thing that the parent does is to ask for an answer, but instead of saying 'this is right or this is wrong', she says 'who has done this the same way?' 'Who thinks that this is whatever?' 'Why?'... Until we reach a point where we all believe in the same answer. (FG2P).

Overall, children agreed that validity claims in the group dialogues enhance their understanding of the subject knowledge. They interpreted learning more deeply when their peers explain the reasons underlying the right answer or procedure instead of just telling the solution straight away, despite that might still happen occasionally. Toni explained:

We understand more because they do not tell you 'this is this way, this is this', but they tell you 'this is not this way, it goes like this because...', so they tell you why it has to be done different... It is when they explain it to you, when they give you the reasons. (FG2ST).

Communicative action is also present in interactive groups. The quotations above indicate that dialogue framed by validity claims is a tool for achieving a state of intersubjectivity, for sharing a state of mind. Pau, for instance, mentioned that students use "reasons" "until a good conclusion is reached", and that volunteers keep asking students for reasons to support their claims "until we reach a point where we all believe in the same answer". Children also related communicative action to more understanding, making the reflection that when they listen to others and try to understand their views, they always learn something new.

In addition, both volunteers and students in interactive groups care for the effects and context of interactions. Children explained that volunteers ensure that everyone in the group speaks so that no one monopolizes the discussion, that all voices are heard, and that validity claims prevail in the dialogues. For all voices

${ }^{1}$ All names used in this article are pseudonyms. 
to be heard, students explained that volunteers call on students who participate less, help language learners shape their thoughts so these students can share their views with the group, check that all students have listened to others' arguments, and ask children who answer questions aloud very fast to wait to hear from others. By doing so, volunteers are creating a more egalitarian participation framework.

Children also demonstrated an understanding of the impact of their actions on others, such as when they consider what kind of actions can either foster or hinder the participation in the dialogues of students who participate less. For example, when talking about newly arrived immigrant students who are language learners, some children reflected about the importance of listening to the contributions of those students:

- Pau: If you have never heard her voice...

- Toni: And you don't listen to her, then you totally discourage her and, afterwards, you will never hear her again.

- Pau: Of course, she will speak much less after you do that. (FG2PT).

All these reflections indicate that, for students, egalitarian dialogues imply helping peers through argumentation, rather than imposing one's view using power claims. It also means adjusting one's explanations to the needs of others in order to achieve intersubjectivity, and caring about the effects of one's words on others with the aim of attaining egalitarian participation in the construction of knowledge in the group.

\section{The instrumental dimension: using dialogue to learn more}

Children understood dialogue as an excellent means for learning not only the content knowledge that is the main focus of the activity but also other knowledge that participants use to support explanations. As Toni described: "Sometimes we start with a problem but from there we go to another one, and we learn two things at the same time, and that's what is good about dialogue". (FG2T).

In addition, children saw dialogue as an instrument for developing communicative abilities and expanding linguistic knowledge: "We learn so much through argumentation, and not only what you are working on in that moment, but many more things, like different forms of expression". (FG2P).

Related to this, both immigrant and native students saw the dialogic dynamics of interactive groups as particularly relevant for enhancing the language learning of newly arrived students because when more proficient students speak in Catalan or Spanish, language learners hear new words and later they try to use them to participate in the dialogue. In Fatima's words:

In interactive groups, since we have to talk and there is oral expression and all of that, while you are talking, they learn because they are trying to unders- 
tand what you say, and they grab words. Later, they try to say those words by themselves, and try to communicate with others. (FG6L).

These two previous quotations show that students use dialogue to talk about the problem that they are solving and to solve it, while at the same time they are conscious that dialogue is an instrument to learn about language.

Additionally, children identified dialogue as a tool for cognitive and personal development. For example, Pau perceived that dialogue affords the development of coherence in reasoning: "Dialogue makes people improve personally, apart from developing vocabulary, it makes them develop coherence (...) Because there are people who are not coherent (...), who are very disperse, who do not relate things properly" (FG2P). Also, Pau used dialogue for meeting an aim that, although related to interactive groups, he had set for himself. This student saw in dialogic interactions in interactive groups the avenue for working on the cognitive task of taking up other students' perspectives, and thus being more persuasive is his interventions in the group:

(...) this is something that I have been willing to work on and that interactive groups have helped me with, is that I place myself in other people's shoes (...) and from there I have seen that there are many ways to be more persuasive... You can then know how they will react, and thus you come to know how to treat some people for making them feel good... (FG2P).

Moreover, children perceived that when explaining to others what they know, they have to revisit their understandings to tell a cohesive story to a diverse audience of students. In that process, they discover holes in their narratives, misconceptions and inconsistencies. In these occasions, dialogue is also enhancing metacognition. Mohamed, for example, explained how dialogue worked for him as a tool to identify errors:

There was one day that I was done with the problem and the volunteer asked me to explain to another child how I had solved it (...). I explained it, and right after, I stayed in silence, thinking, and I realized that I had done his problem right but mine was wrong. So, it was by doing it a second time and explaining it out loud that I realized that I made a mistake. (FG6M).

\section{DISCUSSION}

This study expands knowledge on dialogic processes of learning in various ways. Whereas previous research on learning and discourse in the classroom has mainly studied dialogic learning through observation and discourse analysis (Edwards \& Mercer, 1997; Mercer, 2000; Wells, 1999, 2006), the present study provides a new sight to learning through dialogue by shedding light on children's perceptions of dialogic learning. In particular, the research reported here informs 
of the meanings that children give to learning dialogically in the setting of interactive groups, and describes why dialogic learning is so important to them.

In addition, this investigation makes the important contribution of illustrating with classroom data central concepts of various theories of dialogue, such as the idea of validity claims from Habermas' $(1984,1987)$ theory of communicative action and the notion of egalitarian dialogue (Flecha, 2000). These empirical illustrations are not only of the phenomena described by those theoretical concepts, but notably, the empirical data reflects the meanings that children give to those ideas, something that has been rarely explored for the case of concepts associated to learning.

Importantly, the results of this study also expand exiting knowledge on learning through collaboration in group contexts. Studies of collaborative learning have indicated that it is not only putting children to work together that is essential for enhancing learning in group contexts, but the possibility that certain kind of learning processes can be activated (Cohen, 1994). Among those, are the following: opportunities to share original insights, resolve differing perspectives through argument, explain one's thinking about a phenomenon, provide critiques, observe the strategies of others, and listen to explanations (Barron, 2003). The findings of the present study show that, from children's perspective, egalitarian dialogue creates those opportunities. Children perceived that egalitarian dialogues push them to share their thoughts by engaging in argumentation processes, listening to others' explanations, and making persistent attempts to understand each other's perspectives.

Additionally, while anthropological studies have pointed out that all families and communities have cultural knowledge and tools that they use to enhance their children's school learning (Delgado-Gaitan, 1992, 1994; González, Moll, \& Amanti, 2005), it has been rarely studied how community members use those resources in their interactions with children around instructional activities in classrooms. The findings of this study not only point to ways in which adults from minority groups and with no academic background support children's school learning, but also suggest that these adults can enhance interactions that cultivate inquiry and the dialogic construction of knowledge.

The results of this study also extend research on hybrid learning environments (Gutierrez, Baquedano-Lopez, \& Tejeda, 1999). Previous studies have shown that hybrid learning environments allow students to take alternative paths to understanding and thus favor the engagement of minority students in meaningful and productive ways in school subjects, increasing minority students' opportunities for accessing the knowledge of the traditional school domains (Lee, Spencer, \& Harpalani, 2003). The results of the research reported here show that in interactive groups hybrid avenues of participation are encouraged, among other reasons, because the contributions of all participants are equally valued on the basis of the arguments provided (egalitarian dialogue). What matters the most is not the form children say something or engage in the group dialogues, but what they say and the arguments they provide to support their views. 
Furthermore, studies of cooperative learning have shown that when students with different levels of ability and racial, ethnic, and cultural backgrounds collaborate to solve school tasks, the academic achievement of all students improves (Johnson \& Johnson, 1981; Slavin \& Oickle, 1981). This study on dialogic learning provides some information on the mechanisms through which collaboration raises academic achievement. For instance, children perceived that helping others through argumentation processes aloud and in front of an audience creates possibilities for other students to benefit from the explanation, increases the chances of identifying misconceptions, and the opportunities to fix them.

Overall, the results presented show that when communicative interactions are egalitarian and talk is oriented to learn more, then dialogue can foster all students' learning. Dialogic learning in interactive groups becomes a successful way to approach learning through dialogue in the classroom.

\section{REFERENCES}

Anderson, J. R. (1993). Rules of the mind. Hillsdale, NJ: Erlbaum.

Aubert, A., \& Soler, M. (2006). Dialogism: The dialogic turn in the social sciences. In J. Kincheloe, \& R. Horn (Eds). The Praeger Hanbook of Education and Psychology. (pp. 521-529). Westport, CT: Greenwood Press.

Aubert, A., Flecha, A., García, C., Flecha, R., \& Racionero, S. (2008). Aprendizaje dialógico en la sociedad de la información. Barcelona: Hipatia.

Bakhtin, M. M. (1986). Speech genres and other late essays. Austin: University of Texas Press.

Barron, B. (2003). When smart groups fail. Journal of the Learning Sciences, 12(3), 307-59.

Benson, H. (2000). Socratic Wisdom. Oxford: Oxford University Press.

Bereiter, C., \& Scardamalia, M. (1987). The psychology of written composition. Hillsdale, N.J.: L. Erlbaum Associates.

Bruner, J. (1996). The culture of education. Cambridge, MA: Harvard University Press.

Cohen, E. G. (1994). Restructuring the classroom: Conditions for productive small groups. Review of Educational Research, 64(1), 1-35.

CREA (2006-2011). INCLUD-ED. Strategies for inclusion and social cohesion in Europe from education. FP6 028603-2. Sixth Framework Programme. European Commission.

Delgado-Gaitan, C. (1992). School matters in the Mexican-American home: Socializing children to education. American Educational Research Journal, 29(3), 495-513.

Delgado-Gaitan, C. (1994). "Consejos": The power of cultural narratives. Anthropology \& Education Quarterly, 25(3), 298-316.

Elboj, C., Puigdellívol, I., Soler, M., \& Valls, R. (2002). Comunidades de aprendizaje. Transformar la educación. Barcelona: Graó.

Fisher, R. (2007). Dialogic teaching: Developing thinking and metacognition 
through philosophical discussion. Early Child Development and Care, 177(67), 615-631.

Flecha, R. (2000). Sharing words: Theory and practice of dialogic learning. Lanham, M.D: Rowman\& Littlefield.

Freire, P. (2003). Pedagogy of the oppressed. New York: Continuum.

Frijters, S., ten Dam, G., \& Rijlaarsdam, G. (2008). Effects of dialogic learning on value-loaded critical thinking. Learning and Instruction, 18(1), 66-82.

Gatt, S., Ojala, M., \& Soler, M. (Forthcoming). Promoting social inclusion counting with everyone: Learning Communities and INCLUD-ED. International Studies in Sociology of Education.

Gómez, J., Latorre, A., Sánchez, M., \& Flecha, R. (2006). Metodología comunicativa crítica. Barcelona: Hipatia.

González, N., Moll, L., \& Amanti, C. (2005). Funds of knowledge: Theorizing practices in households and classrooms. Mahwah, New Jersey: Lawrence Erlbaum Associates.

Gutierrez, K. D., Baquedano-Lopez, P., \& Tejeda, C. (1999). Rethinking diversity: Hybridity and hybrid language practices in the third space.Mind, Culture \& Activity, 6(4), 286.

Habermas, J. (1984). The theory of communicative action. V. 1. Reason and the rationalization of society. Boston: Beacon Press.

Habermas, J. (1987). The theory of communicative action. V.2. Lifeworld and system: A critique of functionalist reason. Boston: Beacon Press.

Hutchins, E. (1995).Cognition in the wild. Cambridge, MA: MIT Press.

INCLUD-ED Consortium. (2009). Actions for success in schools in Europe. Brussels: European Commission.

Johnson, D., \& Johnson, R. (1981). Effects of cooperative and individualistic learning experiences on interethnic interaction. Journal of Educational Psychology, 73(3), 444-49.

Lave, J. (1988). Cognition in practice: Mind, mathematics, and culture in everyday life. Cambridge: Cambridge University Press

Lave, J., \& Wenger, E. (1991). Situated learning. Legitimate peripheral participation. Cambridge, M.A: Cambridge University Press.

Lee, C. D., Spencer, M. B., \& Harpalani, V. (2003). "Every shut eye ain’t sleep": Studying how people live culturally. Educational Researcher, 32(5), 6-13.

Mead, G. H. (1934). Mind, self \& society. Chicago, Ill. : University of Chicago Press:

Mercer, N. (2000). Words and minds: How we use language to think together. London: New York: Routledge.

Pinker, S. (1997). How the mind works. New York: W.W. Norton.

Renshaw, P. (2004). Dialogic learning, teaching and instruction: Theoretical roots and analytical frameworks. In J. van der Linden, \& P. Renshaw (Eds.), Dialogic learning (pp. 1-15). Dordrecht, The Netherlands: Kluwer.

Rogoff, B. (1990). Apprenticeship in thinking: Cognitive development in social context. New York: Oxford University Press. 
Salomon, G., \& Perkins, D. N. (1998). Individual and social aspects of learning. Review of Research in Education, 23, 1-24.

Searle, J., \& Soler, M. (2004). Lenguaje y ciencias sociales. Diálogo entre John Searle y CREA. Barcelona: Hipatia.

Slavin, R., \& Oickle, E. (1981). Effects of cooperative learning teams on student achievement and race relations: Treatment by race interactions. Sociology of Education, 54(3), 174-80.

Tharp, R. G., \& Gallimore, R. (1988). Rousing minds to life: Teaching, learning, and schooling in social context. New York: Cambridge University Press.

Vygotsky, L. S. (1962). Thought and language. Cambridge, MA: MIT Press.

Vygotsky, L. S. (1978). Mind in society. Cambridge, MA: Harvard University Press.

Wegerif, R., Mercer, N., \& Dawes, L. (1999). From social interaction to individual reasoning: An empirical investigation of a possible socio-cultural model of cognitive development. Learning and Instruction, 9(6), 493-516.

Wells, G. (1999). Dialogic inquiry: Towards a sociocultural practice and theory of education. New York: Cambridge University Press.

Wells, G. (2001). Action, talk, and text. New York: Teachers College Press.

Wells, G., \& Mejía Arauz, R. (2006). Dialogue in the classroom. The Journal of the Learning Sciences, 15(3), 379-428.

Wenger, E. (1998). Communities of practice: Learning, meaning, and identity. Cambridge: Cambridge University Press. 